University of Nebraska - Lincoln

DigitalCommons@University of Nebraska - Lincoln

Publications, Agencies and Staff of the U.S.

Department of Commerce

U.S. Department of Commerce

\title{
$5-1969$
}

\section{Taxonomy of the Common Dolphins of the Eastern Pacific Ocean}

Richard C. Banks

Robert L. Brownell Jr.

US Fish and Wildlife Service, rlbcetacea@aol.com

Follow this and additional works at: https://digitalcommons.unl.edu/usdeptcommercepub

Part of the Environmental Sciences Commons

Banks, Richard C. and Brownell, Robert L. Jr., "Taxonomy of the Common Dolphins of the Eastern Pacific Ocean" (1969). Publications, Agencies and Staff of the U.S. Department of Commerce. 93.

https://digitalcommons.unl.edu/usdeptcommercepub/93

This Article is brought to you for free and open access by the U.S. Department of Commerce at DigitalCommons@University of Nebraska - Lincoln. It has been accepted for inclusion in Publications, Agencies and Staff of the U.S. Department of Commerce by an authorized administrator of DigitalCommons@University of Nebraska - Lincoln. 


\title{
TAXONOMY OF THE COMMON DOLPHINS OF THE EASTERN PACIFIC OCEAN
}

\author{
Richard C. Banks and Robert L. Brownell
}

\begin{abstract}
Delphinus bairdii Dall is a species of dolphin distinct from D. delphis Linnaeus, with which it has usually been synonymized. $D$. bairdii has a longer rostrum relative to the zygomatic width of the skull; the ratio of these measurements falls at 1.55 or above for bairdii and 1.53 and below for delphis. In the eastern Pacific Ocean, D. bairdii is found in the Gulf of California and along the west coast of Baja California, Mexico; D. delphis is presently found in the waters off California. Until approximately the beginning of the present century, bairdii occurred farther north in the eastern Pacific Ocean, at least to the Monterey Bay area of California. Restriction of bairdii to more southerly waters, probably as an indirect result of a change in water temperature, may have permitted delphis to move into inshore Californian waters. The Pacific population of $D$. delphis has a somewhat shorter rostrum than the Atlantic population, and is perhaps subspecifically different. A thorough analysis of the entire genus Delphinus is needed before the relationship of all the populations can be understood and names properly applied.
\end{abstract}

Common or saddleback dolphins of the genus Delphinus Linnaeus are found in most oceans of the world. A plethora of names has been applied to the various populations and to variants within populations. Most recent classifications (Hershkovitz, 1966; Tomilin, 1967; Scheffer and Rice, 1963) consider that there is but a single species, Delphinus delphis Linnaeus, and there is a consensus that the population of the North Atlantic Ocean, on both European and North American shores, represents the nominate subspecies if subspecies are recognized. The taxonomic treatment of the common dolphins of the eastern Pacific Ocean has been less consistent, however, reflecting an uncertainty as to the true systematic position of that population. Modern cetologists have used the names Delphinus delphis, Delphinus bairdii Dall, and Delphinus delphis bairdii, according to their individual viewpoints and preferences (see Hershkovitz, 1966: 47). Brownell initiated our study to resolve this problem.

\section{History}

The name Delphinus bairdii Dall was based on two female specimens from Cape (now Point) Arguello, Santa Barbara Co., California (Dall, 1873). The only diagnostic cranial characters given for the species were the " ... extremely attenuated beak and very deep channels on each side of the palate behind." Dall stated, however, that: "It differs from all described species of the genus in color and osteological characters. . " Later, Dall (1874) described the skull and cervial vertebrae in some detail, but that description was not comparative and none of the comparisons regarding color or other features was made with "species" or specimens from the Atlantic Ocean. The present location of Dall's specimens is unknown (see Poole and Schantz, 1942: 575).

In an evaluation of the validity of $D$. bairdii, True (1889) considered only the external characters of the species as reported by Dall, and two broken skulls 
from California (San Gabriel River, Los Angeles County, and Monterey, Monterey County) that he assumed to be representative of the Pacific population. True showed that color and pattern were unreliable characters in this genus, and concluded that bairdii should be regarded as identical to delphis, an arrangement that was generally followed until 1936.

On the basis of four additional skulls-from Carmel, Monterey Co., California; San Diego, San Diego Co., California; Escondido Bay, Gulf of California, Mexico; and Korea-Miller (1936) reopened the question of the identity of the Pacific population of common dolphins and concluded that it was distinct from the Atlantic $D$. delphis. The only character on which this evaluation was based was the ". . . peculiar slenderness of the rostrum in the Pacific dolphin..." Slenderness was expressed by the ratio of length of the rostrum to greatest width of the skull at the zygomatic processes of the squamosals. The ratio ranged from 1.39 to 1.53 in eight Atlantic specimens and from 1.69 to 1.74 in the four from the Pacific. The ratio for Dall's specimen is within the range for the Pacific animals.

\section{Results}

Brownell, after measuring a number of Delphinus skulls from Californian waters, found the ratios of rostral length to zygomatic width overlapped completely those given by Miller (1936) for his series of specimens from the Atlantic. We therefore obtained measurements from as many intact specimens as possible from the east and west coasts of North America to determine whether this ratio is actually different in the two populations and, if so, to determine if other distinguishing characters could be found. We examined all the Pacific specimens seen by True and Miller and many more recently taken specimens, a total of 64 useable skulls. Measurements of one specimen as given by Dall (1873) were used. Although our study primarily concerns dolphins from North American waters, we examined and will discuss briefly some extralimital specimens and their bearing on this study.

Some of our mensural data are presented in Figs. 1 and 2. There is apparently no sexual dimorphism in the characters shown, and no variation related to age except for extremely young individuals. Considering the measurements of rostral length and zygomatic width and their ratio, the majority of specimens examined from the Pacific Coast of North America are exceedingly close to Delphinus delphis of the Atlantic Coast. There is, however, a group of specimens that stands apart from all the others. The measurements of Dall's specimen as he recorded them fit well with those of the latter group of longsnouted specimens. We believe that the name Delphinus bairdii Dall must apply to members of that group and that there are two distinct species of saddleback dolphin in the Pacific waters of North America, D. delphis Linnaeus and D. bairdii Dall.

We have found no characters by which $D$. bairdii can be differentiated from D. delphis other than rostral length and ratios dependent on that measurement. 


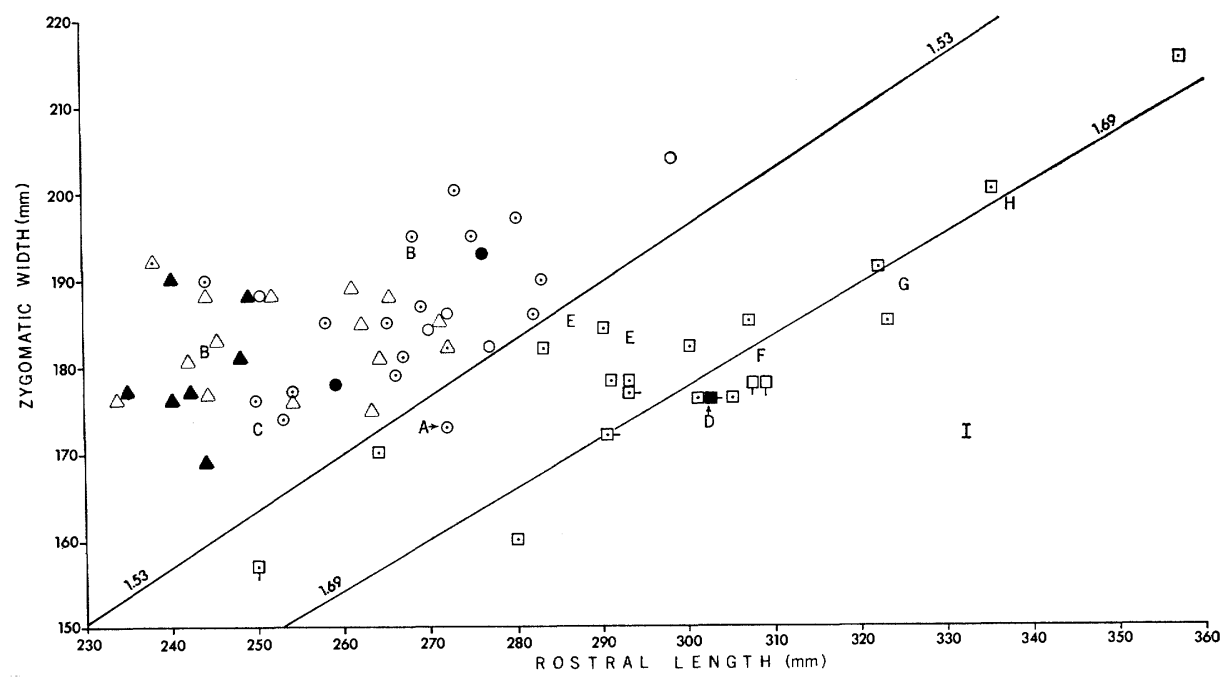

Fig. 1.-Scatter diagram of measurements of rostral length and zygomatic width of specimens of Delphinus. Circles represent delphis specimens from the Atlantic, triangles are delphis from the Pacific, and squares represent bairdii. Hollow symbols are males, solid symbols are females, and dotted symbols are unsexed individuals. A flag to the right of symbols for bairdii indicates a specimen from the coast of California taken prior to 1900; a flag down is a specimen from the west coast of Baja California. The letters indicate: A, narrow-headed specimen from Cape Hatteras; B, specimens from off Costa Rica; C, mean values for $D$. $d$. ponticus as given by Tomilin (1967); D, type of bairdii, measurements from Dall (1873) converted to metric system; E, specimens from Perú; F, specimen from Korea; G, type of D. capensis; H, type of D. major; I, Delphinus sp. from South China Sea. All letters but $\mathrm{A}$ and D replace other symbols. Oblique lines show ratios of 1.53 and 1.69 , the upper limit ascribed to delphis and the lower limit ascribed to bairdii, respectively, by Miller (1936).

Although we consider rostral length to be a valid and meaningful character, we had hoped to find another, independent, feature because the tip of the rostrum is often broken. This breakage, with which all cetologists are familiar, not only reduces the number of specimens that can be used for study, but makes identification of some individuals impossible. We obtained data on total length of skulls, cranial length, width of the rostrum at the notches, width of the rostrum 60 and 100 millimeters from its base, and on various ratios of these measurements. Ratios utilizing the length of the rostrum or the total skull

TABLE 1.-Mean measurements in millimeters of Delphinus skulls used in this study.

\begin{tabular}{lccccc}
\hline & $N$ & $\begin{array}{c}\text { Skull } \\
\text { length }\end{array}$ & $\begin{array}{c}\text { Cranium } \\
\text { length }\end{array}$ & $\begin{array}{c}\text { Zygomatic } \\
\text { width }\end{array}$ & $\begin{array}{c}\text { Rostral } \\
\text { length }\end{array}$ \\
\hline Atlantic delphis & 23 & 436.8 & 168.8 & 186.3 & 267.9 \\
Pacific delphis & 22 & 417.6 & 167.2 & 182.0 & 250.2 \\
bairdii & 20 & 470.3 & 169.8 & 180.0 & 300.2 \\
\hline
\end{tabular}


length (including, of course, the rostrum) provide a clear separation of the populations, but no other treatment of the data will do so. Mean values of some of our measurements are shown in Table 1.

\section{Geographic Distribution}

With few exceptions, the specimens referred to D. bairdii are from the Gulf of California, Mexico, or from the west coast of Baja California. The few specimens from the coast of California were taken before 1900. There are no specimens of the delphis (Atlantic) type from the Gulf of California or from California before 1900, and none of the bairdii (Gulf) type from Atlantic waters. The specimen that True (1889) saw from Monterey and the one examined by Miller (1936) from Carmel are the most northerly examples of bairdii that we have seen. The latter was taken in 1892, the former before 1889. Dall's specimens from Point Arguello were taken in 1872. The specimen mentioned by Miller (op. cit.) from San Diego was taken in 1891. The broken rostrum of True's specimen from the mouth of the San Gabriel River prevents a definite identification, but the slenderness of the rostrum suggests that it is bairdii; it was taken in 1875 .

We have seen but three specimens of bairdii from the west coast of Baja California, all taken in the 1950's. From south to north, the localities represented are: Magdalena Bay; off Cedros Island; and San Martín Island. The latter is the most northerly specimen of bairdii obtained outside the Gulf of California in recent years.

We have examined two specimens from the coast of Perú. Measurements and ratios of these specimens fit those of bairdii from the Gulf of California. Thus it appears that there is a bairdii-like population of dolphins in the eastern South Pacific Ocean. On the other hand, we have referred two specimens from Pacific waters off southern Costa Rica to D. delphis.

Okada and Hanaoka (1938) reported that D. delphis, in which bairdii was included, was common off Japan, and reported a study of nine specimens. Since measurements of zygomatic breadth were not given, we are unable to correlate their data with ours. Both Tomilin (1967) and Hershkovitz (1966) included Japan within the range of $D$. delphis bairdii, and Miller (1936) included a specimen from Korea among those that he considered to be $D$. bairdii. We have examined that Korean specimen and find that it is indeed indistinguishable from the eastern Pacific bairdii.

Thus, we consider the distribution of Delphinus bairdii to be disjunct, with one population centered around the Gulf of California, another in the waters off Japan and Korea, and possibly a third off the Pacific coast of South America. We realize, however, that study of additional material from the Pacific may change this tentative evaluation.

Several recently-taken specimens of delphis are available from southern California, the southernmost being from La Jolla, San Diego County. Our entire series of Pacific delphis was from southern Californian waters. The 
northern limits of this species along the Pacific Coast are not well documented, but it occurs only sparingly north of central California. We have referred two specimens from off southern Costa Rica to delphis, as noted above, suggesting that this species may have a disjunct distribution in the Pacific waters of North and Central America.

\section{VARIATION}

It appears from our data that Miller (1936) overestimated the extent of difference between the species bairdii and delphis, probably because he had so few specimens of the former. Using the ratio of rostral length to zygomatic width, the two species separate at 1.53 to 1.55 , bairdii having the higher ratios and thus a relatively longer rostrum. We have seen but a single instance of overlap of these measurements-a specimen from Cape Hatteras, North Carolina, with a ratio of 1.57. Dr. Charles O. Handley (personal communication) has pointed out that the high ratio for this Atlantic specimen results not from a long rostrum but rather from a narrow skull. The zygomatic width of that specimen is at least a centimeter less than in other specimens with rostra of comparable length. One young individual of bairdii (skull length only 331 , rostrum 193, zygomatic width 125 millimeters) had a ratio of 1.54 . Because of the small size of this specimen, it was not included in the statistical analysis nor plotted on Figs. 1 and 2 .

Our decision to recognize bairdii at the specific level rather than as a subspecies of delphis is based partly on the fact that there is no indication of intergradation between the populations. The three specimens taken recently from the west coast of Baja California are nearest geographically to present delphis populations, and if genetic exchange occurs one would expect evidence of it in that sample. The three specimens from that area, however, have rostra as long as those from the Gulf of California (Fig. 3), not shorter as would be expected if there was some genetic influence from delphis.

Another factor in our decision is the degree of difference between bairdii and delphis, compared to the difference between populations within the latter species. With bairdii excluded, D. delphis consists of only two currently recognized subspecies-nominate delphis, over most of the world, and $D . d$. ponticus Barabasch, in the Black Sea (Hershkovitz, 1966; Tomilin, 1967), the latter population distinguished by its small size (Tomilin, op. cit.:515). Tomilin (op. cit.:477) presented average measurements for the 13 largest of his skulls of Black Sea dolphins. Although we recognize that the ratio between average measurements is not strictly comparable to our series of individual ratios, we have plotted these means and their ratio on Figs. 1 and 2. The ratio of 1.45 fits well within the range of variation for Atlantic and Pacific samples of D. delphis, emphasizing the distinctness of bairdii.

In order to point out the distinctness of bairdii from populations of delphis in both Atlantic and Pacific waters of North America, we have considered the latter two populations as a unit. An unexpected result of this study was the 


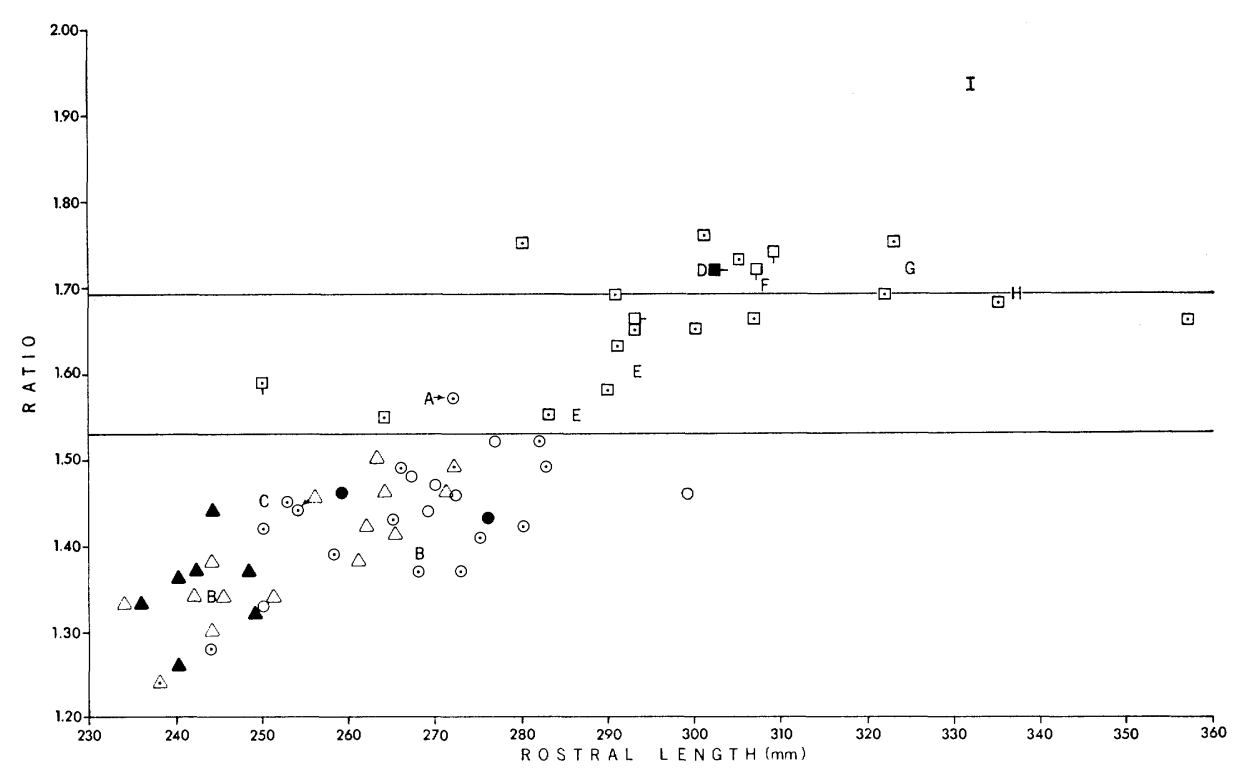

FIG. 2.-Scatter diagram relating the ratio of rostral length to zygomatic width, to the length of the rostrum of specimens of Delphinus. Symbols as in Fig. 1. Oblique lines from Fig. 1 are horizontal in Fig. 2.

discovery that these two populations actually differ in the relative length of the rostrum. The Pacific population, geographically nearest to the long-snouted bairdii, has a considerably shorter rostrum than the Atlantic series. Although there is much overlap in actual measurements and in the values of the ratio of the rostral length to the zygomatic width, the means of the ratios differ significantly at the 99 per cent level of probability according to the Student's $t$-test. Subspecific status might properly be awarded the eastern Pacific population of $D$. delphis, but we are reluctant to propose a trinomial at this time because we have not thoroughly studied the variation in that species and we are uncertain of the application of the many names already available.

\section{Adjustment of Geographic Distribution}

We suggest that our data indicate a relatively recent adjustment of the range of bairdii and possibly of delphis in the eastern Pacific Ocean. Until about the turn of the century, bairdii was found in the costal waters of central and southern California. Since that time bairdii has apparently withdrawn southward, and may have been replaced in Californian waters by delphis. The present range of bairdii in the Gulf of California may thus be viewed either as a restriction of a former range, which extended several hundred miles farther north, or as a newly occupied range. We prefer the former view. The present occupant of Californian waters, delphis, may have moved in from farther north or from farther offshore, or may have occurred with bairdii. We have seen no specimen of delphis from the Pacific Coast that were collected prior to 1934. 


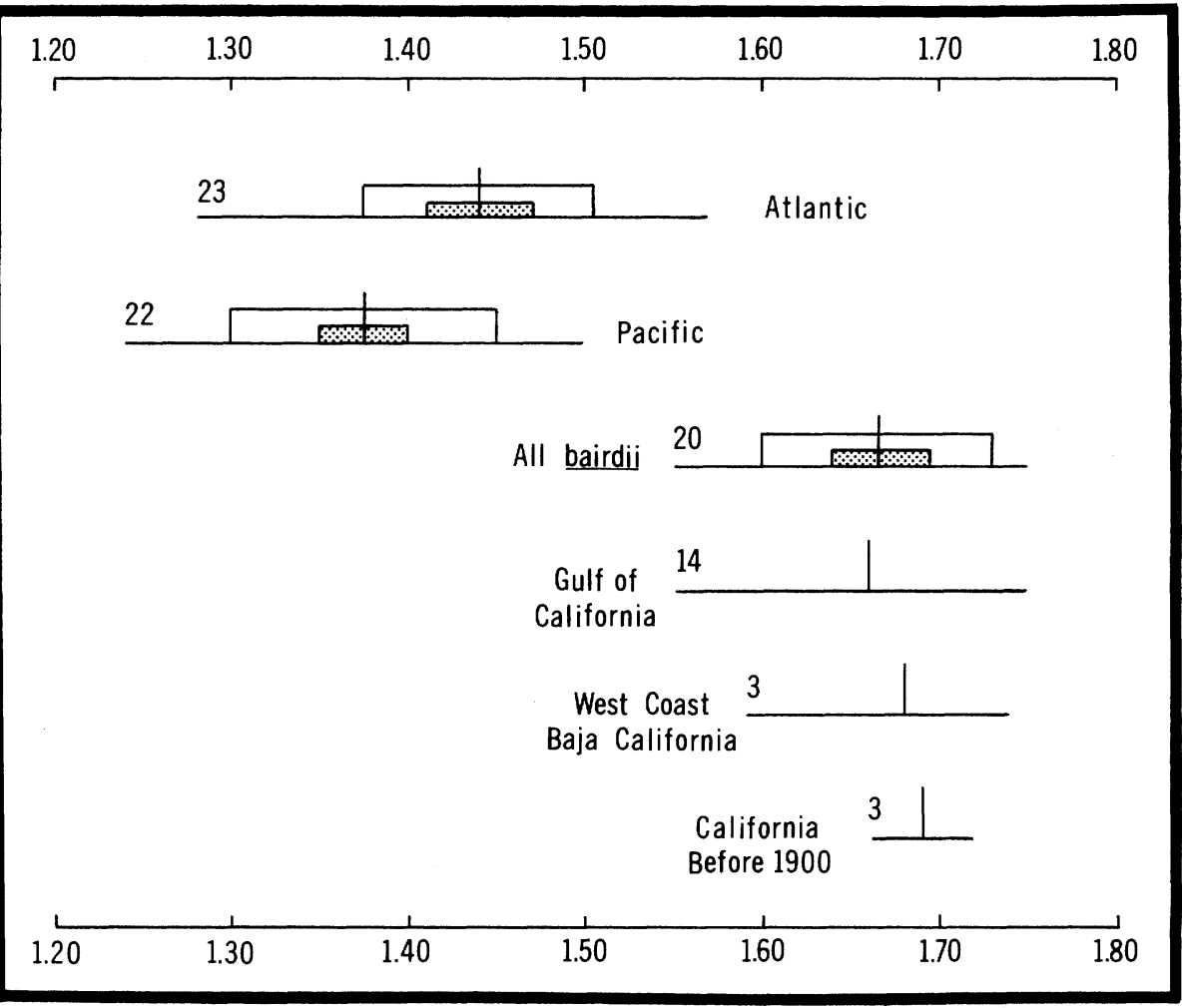

FIG. 3.-Comparison of ratio of rostral length to zygomatic width for samples of three populations of Delphinus. Horizontal line represents the range; vertical line, the mean; hollow rectangle, standard deviation; stippled rectangle, twice the standard error of the mean; and number at end of each horizontal line, sample size. D. bairdii is broken into constituent populations, for which only the mean was calculated.

We further suggest that the change of range by bairdii, and possibly delphis, which apparently took place about the beginning of the present century, was related to changes in water temperature along the coast of southern California. Some aspects of the effects of water temperature on cetaceans have been discussed by Davies (1963). Radovich (1961) has documented the effect of water temperature on the distribution of a wide variety of marine organisms, including at least one cetacean. He noted (op. cit.:53) that female sperm whales appear to avoid waters of $17^{\circ} \mathrm{C}$ or colder, seldom venturing beyond $40^{\circ} \mathrm{N}$, but recorded that the percentage of female sperm whales in the catches of the shore whaling station at Coal Harbor, Vancouver Island, British Columbia, was high in 1957, at the beginning of a period of warm water moving north along the Pacific Coast.

Hubbs (1948) discussed a strong infusion of warmer water fishes into southern Californian waters, and of southern Californian fishes into the Monterey 
area in the middle of the last century, and stated: "The 1850 and 1860 decades appear to have been in a prolonged warm period." He also commented that “. . a considerable representation of southern types seems to have persisted through the 1870 's until $1880 \ldots$..." in the Monterey area.

In support of our hypothesis, we note that a similar restriction to more southerly waters has apparently taken place in another cetacean species of the eastern Pacific, the Pacific bottle-nosed dolphin, Tursiops gillii Dall. The type locality for this species is Monterey Bay, California (Dall, 1873); only one specimen is known from farther north, a cranium found recently in San Francisco Bay and estimated to have been in the water for 50 to 100 years (Orr, 1963). The most northern recent specimen record of $T$. gillii is a skull from San Diego County, California (Kenyon, 1952). Although there are records for the genus Tursiops from somewhat farther north (Norris and Prescott, 1961), skulls from which specific identifications can be verified are not available.

We do not mean to imply that distribution of cetaceans is directly related to water temperature. Rather, we suspect their distribution may reflect that of favored prey fish species, which is in turn dependent on water temperature either directly or indirectly. The fact that the major differentiating character between Delphinus bairdii and D. delphis is the length of the rostrum, an adaptive feature probably related to feeding, suggests that the food habits or preferences of the two species may differ somewhat.

\section{Need for Additional Study}

Our study has emphasized that the entire genus Delphinus is in need of taxonomic revision. Recently Brownell had the opportunity at the British Museum (Natural History) to measure the skulls of the type specimens of D. major Gray and $D$. capensis Gray, both synonymized with $D$. delphis by Hershkovitz (1966) and others. Considering the ratio of rostral length to zygomatic width, both these specimens fit our concept of $D$. bairdii. We have seen but one specimen that does not fit with either delphis or bairdii. That individual (USNM 49977, South China Sea) has a rostral length of 332 millimeters, a zygomatic width of 172 , and a ratio of 1.93 , much greater than any other specimen we examined. We are not certain what name should be applied to that specimen.

We are not at this time proposing that either of the names major or capensis applies to the populations of common dolphin in the Pacific that we have referred to bairdii. We do feel, however, that synonymizing all species names in Delphinus under the single specific name delphis is an extreme oversimplification.

\section{SPECIMENS EXAMINED}

D. delphis.-AtLantic. Canada: off Nova Scotia, 4 (USNM). Massachusetts: Woods Hole, 2 (USNM). Rhode Island: Block Island, 1 (USNM). New York: near Highland, Alster Co., 1 (AMNH); New York Harbor, 1 (USNM); Hudson River, 2 (AMNH), 1 (USNM); Staten Island, 1 (AMNH); Fire Island Beach, 1 (AMNH). New Jersey: Jersey 
City, 1 (AMNH). Virginia: Cobbs Island, 1 (USNM); Dam Neck Mills, 1 (USNM). North Carolina: Moorehead City, 1 (AMNH); Cape Hatteras, 4 (USNM). Florida: Miami, 1 (USNM).

D. delphis.-PACIFIC. California: no specific locality, 1 (LACM); southern California, 4 (W. Walker coll.); Catalina Island, 2 (SDNHM), 1 (LACM); between Catalina Island and Osborn Bank, 4 (SDNHM); San Diego Co., 1 (SDNHM); Solana Beach, 1 (SDNHM); La Jolla, 2 (SDNHM), 1 (Perrin coll.); $33^{\circ} 30^{\prime} \mathrm{N}, 118^{\circ} 17^{\prime} \mathrm{W}, 1 ; 33^{\circ} 15^{\prime} \mathrm{N}, 119^{\circ} 02^{\prime} \mathrm{W}, 1$; $35^{\circ} 52^{\prime} \mathrm{N}, 121^{\circ} 31^{\prime} \mathrm{W}, 1 ; 35^{\circ} 31^{\prime} \mathrm{N}, 121^{\circ} 35^{\prime} \mathrm{W}, 1 ; 32^{\circ} 40^{\prime} \mathrm{N}, 114^{\circ} 00^{\prime} \mathrm{W}, 1$ (last 5 all D. W. Rice coll.). Costa Rica: $8^{\circ} 14^{\prime} \mathrm{N}, 84^{\circ} 17^{\prime} \mathrm{W}, 2$ (USNM).

D. bairdii.-California: Monterey, 1 (USNM, damaged); Carmel Bay, 1 (USNM); mouth of San Gabriel River, 1 (USNM, damaged); San Diego, 1 (USNM). Baja California: San Martín Island, 1 (MVZ); off Cedros Island, 1 (MVZ); Magadalena Bay, 1 (MVZ). Gulf of California, Baja California: Campo Paraiso, $9 \mathrm{mi}$. N San Felipe, 1 (SDNHM, juv.); north of San Felipe, 1 (LACM); San Felipe, 1 (LACM); south of San Felipe, 1 (LACM); Puertocitos, 2 (LACM); 2 mi. N San Luis Gonzaga Bay, 1 (CAS); San Luis Gonzaga Bay, 1 (LACM); Isla Angel de la Guarda, 1 (CAS); Partida Island [Norte], 1 (SDNHM); Mulegé, 1 (D. Rice coll.); Puerto Escondido = Escondido Bay, 2 (CAS), 1 (USNM); near San Telmo Point, 1 (AMNH). Perú: no specific locality, 2 (FMNH). Korea: SE coast, 1 (USNM).

D. major.-no locality, 1 (BMNH, the type).

D. capensis.—off Cape of Good Hope, 1 (BMNH, the type).

D. species.-near East India Islands, South China Sea, 1 (USNM).

No record was kept of most damaged skulls or specimens with inadequate data, although the number of these examined was large.

\section{ACKNOWLEDGMENTS}

Through the courtesy of the respective curators, we were able to examine and obtain measurements from skulls in the following museum collections: American Museum of Natural History (AMNH), New York; British Museum (Natural History) (BMNH), London; California Academy of Sciences (CAS), San Francisco; Field Museum of Natural History (FMNH), Chicago; Los Angeles County Museum of Natural History (LACM), Los Angeles; Museum of Vertebrate Zoology (MVZ), Berkeley; San Diego Natural History Museum (SDNHM), San Diego; and United States National Museum (USNM), Washington. Dale W. Rice provided measurements of specimens in the Bureau of Commercial Fisheries collection at the Marine Mammal Biological Laboratory, Seattle. Specimens in private collections of William F. Perrin and William Walker also were examined.

Dr. Charles O. Handley, Jr., and John L. Paradiso read early drafts of the manuscript and offered many valuable suggestions. With the courteous assistance of Dr. Henry M. Setzer and Duane Schlitter we were able to determine the statistical significance of our data on computer facilities of the Smithsonian Institution. Robert L. DeLong aided in measuring some of the specimens. The illustrations were prepared by Keenan Poulson.

This paper is contribution no. 12, Pacific Ocean Biological Survey Program, Smithsonian Institution, Washington, D. C.

\section{Literature Cited}

DALL, W. H. 1873. Preliminary descriptions of three new species of Cetacea, from the coast of California. Proc. California Acad. Sci., 5: 12-13.

1874. Catalogue of the Cetacea of the North Pacific Ocean. In Scammon, C. M., Marine mammals of the northwestern coast of North America, described and illustrated ... with an account of the American whale-fishery. John H. Carmary and Co., San Francisco, 319 pp.

DAvies, J. L. 1963. The antitropical factor in Cetacean speciation. Evolution, 17: $107-116$. 
Henshkovitz, P. 1966. Catalog of living whales. Bull. U. S. Nat. Mus., 246: 1-259.

Hubss, C. L. 1948. Changes in the fish fauna of western North America correlated with changes in ocean temperature. J. Marine Res., 7: 459-482.

KenYon, K. W. 1952. A bottlenose dolphin from the California coast. J. Mamm., 33: 385-387.

Miller, G. S., Jr. 1936. The status of Delphinus bairdii Dall. Proc. Biol. Soc. Washington, 49: 145-146.

Norris, K. S., AND J. H. Prescott. 1961. Observations on Pacific cetaceans of Californian and Mexican waters. Univ. California Publ. Zool., 63: 291-402.

Okada, Y., and T. Hanaoka. 1938. A study of Japanese Delphinidae (II). Sci. Repts. Tokyo Bunrika Daigaku, sect. B., 3: 243-267.

ORR, R. T. 1963. A northern record for the Pacific bottlenose dolphin. J. Mamm., 44: 424.

Poole, A. J., ANd V. S. Schantz. 1942. Catalog of the type specimens of mammals in the United States National Museum, including the Biological Survey collection. Bull. U. S. Nat. Mus., 178: 1-705.

Radovich, J. 1961. Relationships of some marine organisms of the northeast Pacific to water temperatures particularly during 1957 through 1959. Fish Bull., California Dept. Fish and Game, 112: 1-62.

ShefFer, V. B., AND D. W. Rice. 1963. A list of the marine mammals of the world. Special Sci. Rept. no. 431, Bureau Commercial Fisheries, Washington, 12 pp.

Tominin, A. G. 1967. Mammals of the U. S. S. R. and Adjacent Countries [trans. from Russian]. Publ. Israel Program for Scientific Translations, Jerusalem, 9: 1-717.

True, F. W. 1889. Contributions to the natural history of the cetaceans, a review of the family Delphinidae. Bull. U. S. Nat. Mus., 36: 1-191.

Bird and Mammal Laboratories, Bureau of Sport Fisheries and Wildlife, U. S. National Museum, Washington, D. C. 20560, and Pacific Ocean Biological Survey Program, Smithsonian Institution, Washington, D. C. 20560 (present address of Brownell: Los Angeles County Museum, 900 Exposition Blvd., Los Angeles, California 90007). Accepted 19 January 1969. 